\title{
Saskatchewan Tree Farms
}

By C. STUART FRANCIS, Torch River

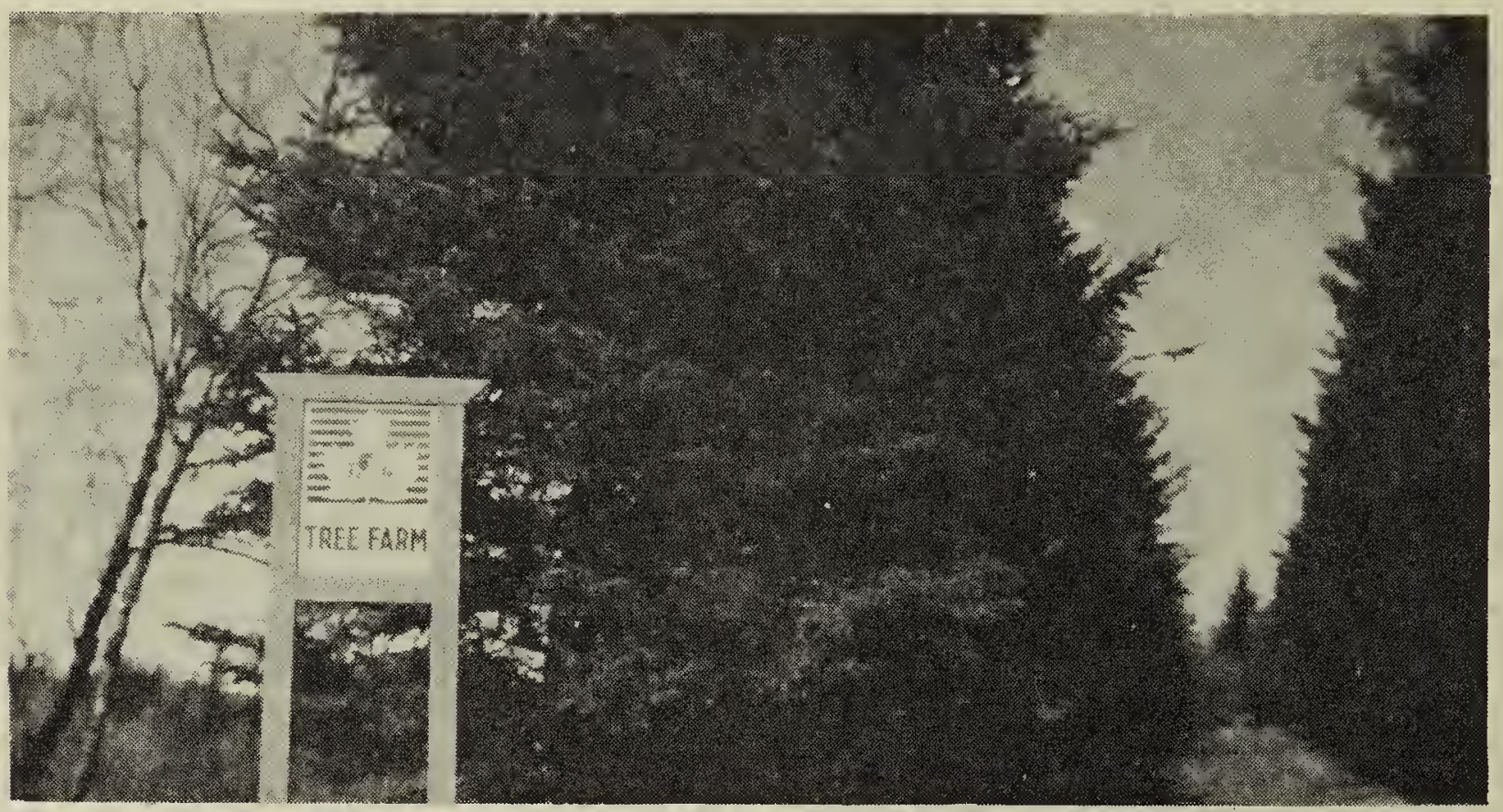

Tree Farm No. 51, the first tree farm to be certified in the three prairie provinces. Owned by C. Stewart Francis and Sons, Torch River, Sask.

The Canadian Tree Farm Movement in Saskatchewan is slowly but surely moving ahead in its objective of achieving its aims which are the conservation and proper management of privately owned woodlots, all across the Dominion.

Initally organized a little over two years ago in this province, progress has been slow but steady. To date, October 4, 1955, the first farm woodlots in Saskatchewan were officially certified as "Tree Farms", by the Canadian Forestry Association's national tree farm committee. Three Tree Farm Certificates were presented to two Tree Farmers in the Torch River district, and one in the Candle Lake area, during a ceremony held at Prince Albert in conjunction with a meeting of the Canadian Institute of Forestry which was held this year in Saskatchewan in honour of the Province's jubilee.

In addition to Tree Farms already established, dozens of Farm woodlot owners throughout the forest region of Saskatchewan are showing much interest in the tree farm program, and most owners have declared their intention of participating in the program.

Woodlot owners are agreed that proper management is the only way in which maximum returns may be realized from farm woodlots, and most owners also realize that the maintenance of areas of forest land scattered all through the farming region in which trees grow naturally, is the one sure way of keeping nature in balance. Only by keeping nature in balance can farming continue to remain prosperous, for trees are the greatest insurance against loss of moisture, loss of topsoil through wind and water erosion. Trees also maintain our surface and underground water supplies, which are the life blood of our existence of every form of life be it human, animal or plant.

We in Saskatchewan should rejoice in the fact that we have become the first of the three prairie provinces to recognize the benefits of proper management of farm woodlots, and to be proud of the recognition of our responsibilities in retaining our farm and private forest lands in good ecological balance. What better year could have been chosen than the year 1955, Saskatchewan Jubilee Year.

We have made a good beginning in our efforts to maintain our woodlots in a more profitable and practical condition but we have really only scratched the surface so far. Compared to other farm crops, trees grow slowly, or appear to do so. I am sure, however, that in a few decades we will all be greatly surprised with the (continued on page 24) 


\section{The Blue Jay Bookshelf}

\section{"WINGS IN THE WIND"}

By ANNE MERRILL, Toronto: The Ryerson Press, 1954

Review by MARGARET BELCHER

A column of Anne Merrill's that appeared every Saturday morning for ten years in the Toronto Globe and Mail provides the inspiration and title for her book Wings in the Wind. R. A. Farquharson, who was editor of the Globe and Mail when the column began, comments on how it "was tossed into the cold columns of type and left to sink or soar: and how well the wings have fared in the wind ever since!" The qualities that made that feature a must in a crowded Saturday paper insure the popularity of Anne Merrill's book with the general reading public. For one thing, the writer is obviously interested in people as well as in birds. Her style is deliberately popular rather than scientific. In this way, she hopes to encourage even those who have never thought about the birds around them to enter a "realm of magic" which she has known from childhood.

In appealing to the general reader, Anne Merrill writes of the heralds of spring and of the flower birds, of voices of the marsh and wings over the water, of birds that ride the wind, and last of all, of birds that brave the snow. At first, her observations about them seem deceptively simple. She disarms any reader who feels that he himself knows nothing about birds by proceeding from the familiar to the less familiar. She takes the theme, "Just turn and look out of your own window", and reminds us that "there is no lovelier bird than the robin — a wild bird at our very door". From there she branches out to give all kinds of interesting bits of information, much of which will be digested enthusiastically by even the more experienced bird watcher.

In making her observations, Anne Merrill is careful not to discourage the reader by a technical vocabulary. In case you should find a name like Semipalmated Plover rather forbidding, she admits herself to calling the bird Little Killdeer "when no scientists are listening in". Actually, of course, Miss Merrill does not scorn the scientists or their contributions to knowledge, but she is anxious that the man on the street should feel that he has a very real place in bird study. Bird lore as Anne Merrill gathers it comes first from observations made by herself or others who know her through her column. The experts are introduced only to supplement or confirm these observations, and the names of eminent ornithologists like Forbrush, F. H. Kortright, J. Dewey Soper, P. A. Taverner, slip into the text as casually as friends' names in a conversation. They have to share the honours with "a woman on Ward's Island who reported that she saw..."

This conversational approach to the reader is the strength of the book, although the style sometimes seems strained when Anne Merrill is too brightly anxious on behalf of the birds "to win friends and influence people". For the most part, however, what she writes has the virtues of simplicity and directness and with these a certain colour that comes from the capacity for apt description. Anne Merrill is also sensitive to the poetry of nature, and there are telling imaginative phrases in which she captures the spirit of "wild little warblers" with "restless wings and lisping notes", etc. After reading the book, you know you would have enjoyed having Anne Merrill's column at your breakfast table every Saturday morning.

\section{SASKATCHEWAN TREE FARMS}

(continued from page 23)

improvement of our farm forests. The woodlot owner who practices good forest management will receive both financial and aesthetic benefits much greater than he can envision today.

Let Saskatchewan continue to lead the way to better Farm Woodlots in the prairie provinces and by so doing, show the rest of Canada that we can grow good trees as well as the best wheat and the best livestock in the Dominion. When another jubilee year rolls around fifty years hence we will be able to look up to and be proud of our "Trees for Tomorrow". 